CORRECTION

\title{
Correction to: No Case Against Disjunctive Properties
}

\author{
Xinkan Zhao ${ }^{1,2} \mathbb{D}$
}

Published online: 15 November 2021

(c) Springer Nature B.V. 2021

\section{Correction to: Philosophia https://doi.org/10.1007/s11406-021-00346-2}

The original version of the article unfortunately contained mistakes. The in-text numbers and contents of body footnotes were mismatched starting from footnote 4. In addition, final pages will also be added in reference citations with unknown $(\mathrm{xxxx})$ pages.

The original article has been corrected.

Publisher's Note Springer Nature remains neutral with regard to jurisdictional claims in published maps and institutional affiliations.

The original article can be found online at https://doi.org/10.1007/s11406-021-00346-2.

Xinkan Zhao

zhaoxinkan@pku.edu.cn

1 Department of Philosophy, Peking University, Beijing, China

2 Institute of Foreign Philosophy, Old Chemistry Building, Peking University, 5, Yihe Yuan Rd., Haidian District, Beijing 100871, China 